\title{
Characterization and Shelf Life of Semi-preserve Black Caiman (Melanosuchus niger) Meat
}

\author{
Ariane M. Kluczkovski (Corresponding Author), Vanessa Ale, Samir Pinto, Allyne Silva, \\ Augusto Kluczkovski-Junior
}

Federal University of Amazonas, Brazil

Received: June 22, 2020

Accepted: July 12, 2020

Published: August 4, 2020

doi:10.5296/jas.v8i4.17477

URL: https://doi.org/10.5296/jas.v8i4.17477

\begin{abstract}
Some conservation methods can add value to the product involved, especially those that involve meat derivatives. To take advantage of the raw materials available in the Amazon region, a semi-preserve using the meat of black caiman (Melanosuchus niger) was elaborated and evaluated for 90 days. The product was prepared using a curing brine of $4 \%$ acetic acid and $5 \%$ sodium chloride $(\mathrm{NaCl})$, tail meat and back strap (sirloin), and was maintained at a controlled temperature of $5{ }^{\circ} \mathrm{C}$ for $30 \mathrm{~d}$., with subsequent addition of flavoring brine (olive oil or Brazil nut oil), seasoning and soy lecithin for emulsification. The product was pasteurized at $70{ }^{\circ} \mathrm{C} / 20 \mathrm{~min}$ and stored at $25^{\circ} \mathrm{C} / 90 \mathrm{~d}$. The proximate composition, $\mathrm{pH}$, acidity index, total volatile base nitrogen (TVBN), were determined. In the microbiological analysis for Salmonella sp., total coliforms and E. coli were within the standards required by current Brazilian legislation. The results of the physical-chemical analyses showed that the product had remained stable during the $90 \mathrm{~d}$. of storage at room temperature $\left(25^{\circ} \mathrm{C}\right)$, and the $\mathrm{pH}$ values confirm that the immersion in acetic acid and sodium chloride in the proposed concentrations were enough to promote the reduction of $\mathrm{pH}$ and thus maintain the stability of the product.
\end{abstract}

Keywords: Melanosuchus niger, $\mathrm{pH}$, Acidity, TVBN

\section{Introduction}

Considering the global concern with environmental preservation, it is not acceptable to base the production chain of alligators on only one product, while discarding the other. It is necessary to make full use of the two products: meat and skin. After decades of exploitation solely for the hides, the meat of crocodilians is once again being legally exploited in Brazil (Figueiredo et al., 2015). Caiman meat is nutritionally rich and is part of the dietary habits of traditional societies (Isaac et al., 2015). In Brazil, crocodilians for human consumption are raised in two manners: (a) by farming (captivity) and (b) by ranching (wild harvesting) 
(Dantas Filho et al., 2020). The wild animals are important food sources and can be exploited commercially by native populations in the Amazon region (Kluczkovski Junior et al., 2016). There is also an emerging market for exotic meats, and reptiles represent an alternative source of protein for human consumption. They are a healthy option and can be transformed into renewable sources of highly profitable products. Despite the availability of farmed animals, the consumption of meat from wild animals has increased and there is now a demand in foreign markets (Cawthorn \& Hoffman, 2016). On the other hand, the supply of this product in its wild variety is low, and the production rates from ranching fluctuate. To reduce illegal hunting in susceptible areas, training and technology transfer programs must be implemented in traditional areas, since the trade in wildlife species contributes to the economic progress of the indigenous and rural populations of a country (Marioni et al., 2013). In view of the potential of the alligator production chain in the Amazon region, and the lack of strategies that seek better economic use, both for its conservation and better management, as well as for the elaboration of products and by-products, it is necessary to develop strategies to conserve and add value to this chain. The semi-preserve is one meat conservation method used in the production of various fish by-products in which thermal treatment is applied. Usually, the marinated process occurs in parallel to the maturation process. The maturation is a physicochemical event, and is carried out in the first step of the marination, which consists of several stages, and in which salt and acetic acid have a parallel effect on the fish meat (Dercioglu et al., 2019). The process of marinating fish by-products is used for fresh water and marine fish species and provides us with a product that has an extended shelf life and is a nutritional alternative (Szymczak, et al., 2019). This process has already been applied to commercial fish species from the Amazon region, such as pirarucu (Arapaima gigas) and tambaqui (Colossoma macropomum), and both are species with good meat yield and are suitable for use in several preservation processes, such as vacuum packing, salting, refrigerating or freezing (Coutinho et al., 2019; Carpio et al., 2018). In this kind of preservation technology, oils and other ingredients can be used (Mesias et al., 2015). In marinated anchovy (Engraulis encrasicolus) fillets, for example, olive leaf extract (Olea europaea) improves their shelf life without modifying the organoleptic characteristics of the product (Testa et al., 2019). In this sense, extracts or oils from the Amazon could also be applied. Brazil nut oil, for example, has great nutritional and technological potential, mainly due to the quantity of lipids, and its fatty acid profile consists mainly of unsaturated fatty acids, oleic and linoleic acid (Zanqui et al., 2020). It stands out for being one of the food products with great industrial interest, since many companies seek more profitable and economical isolation and/or extraction of lipids, and future commercial applications that can lead to a good cost-benefit ratio and great development in the experimental field. Given this scenario, the objective of the study was to produce a semi-preserve from Amazonian alligator meat with Brazil nut oil and subsequently evaluate the product's shelf life.

\section{Materials and Methods}

\subsection{Preparation of the Product}

For the preparation of the marinade, data collection was carried out with various sources of information regarding ingredients, such as \% of acids, \% of $\mathrm{NaCl}$. The amount of meat in the 


\section{Macrothink

two formulations were calculated, and the variable between the recipes was the type of oil used: (a) Brazil nut oil and (b) olive oil.

\subsection{Raw Materials}

We used commercial alligator back strap (sirloin) and tail meat purchased from the RESEX Lago do Cuniã, Rondônia State, Brazil. The pieces were thawed at a temperature of $2-10{ }^{\circ} \mathrm{C}$, and then cut to a size of $7 \times 2 \mathrm{~cm}$ and separated into the following quantities: $3.230 \mathrm{Kg}$ of back strap and $5.065 \mathrm{Kg}$ of tail meat.

\subsubsection{Preparation of the Curing Brine}

A ratio of $4 \%$ acetic acid ( $4 \%$ p.a.) + deionized water $+\mathrm{NaCl}$ at $5 \%$ was used. The ingredients were measured and mixed to create the curing brine and maintained at a temperature of $5{ }^{\circ} \mathrm{C}$ for a period of $30 \mathrm{~d}$., and the $\mathrm{pH}$ was measured daily.

\subsubsection{Preparation of Flavoring Solution}

After the curing period, the brine content was drained, the cuts were dried with paper towels and the flavoring solution was added. In this phase, solutions of $2 \mathrm{~L}$ were made and contained the proportions as described in Table 1.

Table 1. Proportions of flavoring solution (proportion for each brine of 2 liters)

\begin{tabular}{lcc}
\multicolumn{1}{c}{ Ingredient } & Concentration (\%) & Quantity \\
\hline Soy lecithin (mL) & 1 & 20 \\
Oil (Brazil nut or olive oil) $\mathrm{mL}$ & 5 & 100 \\
Acid solution $(\mathrm{mL})$ & 4 & 235 \\
$\mathrm{NaCl}(\mathrm{g})$ & 5 & 80 \\
Black pepper $(\mathrm{g})$ & 1 & 20 \\
$\mathrm{Cumin}^{\mathrm{C}} \mathrm{Coriander}{ }^{1}(\mathrm{~g})$ & 1 & 20 \\
Garlic $^{1}(\mathrm{~g})$ & 0.8 & 16 \\
Onion $^{1}(\mathrm{~g})$ & 1 & 20 \\
\hline
\end{tabular}

\footnotetext{
${ }^{1}$ Powdered
}

\subsubsection{Packaging And Pasteurization}

Approximately $120 \mathrm{~g}$ of meat and flavoring solution were added to each glass jar. The jars were closed manually and placed in a water bath for $20 \mathrm{~min} / 70{ }^{\circ} \mathrm{C}$. The cuts, with their 
respective oils, were identified with the following acronyms: TMB (tail meat/Brazil nut); TMO (tail meat/olive oil), BSB (back strap/Brazil nut) and BSO (back strap/olive oil). After cooling, the jars were stored in cardboard boxes and maintained at room temperature for a period of $90 \mathrm{~d}$., after which, analyses were carried out to check the quality of the product. The production was carried out in triplicate and the flowchart can be seen in Figure 1.

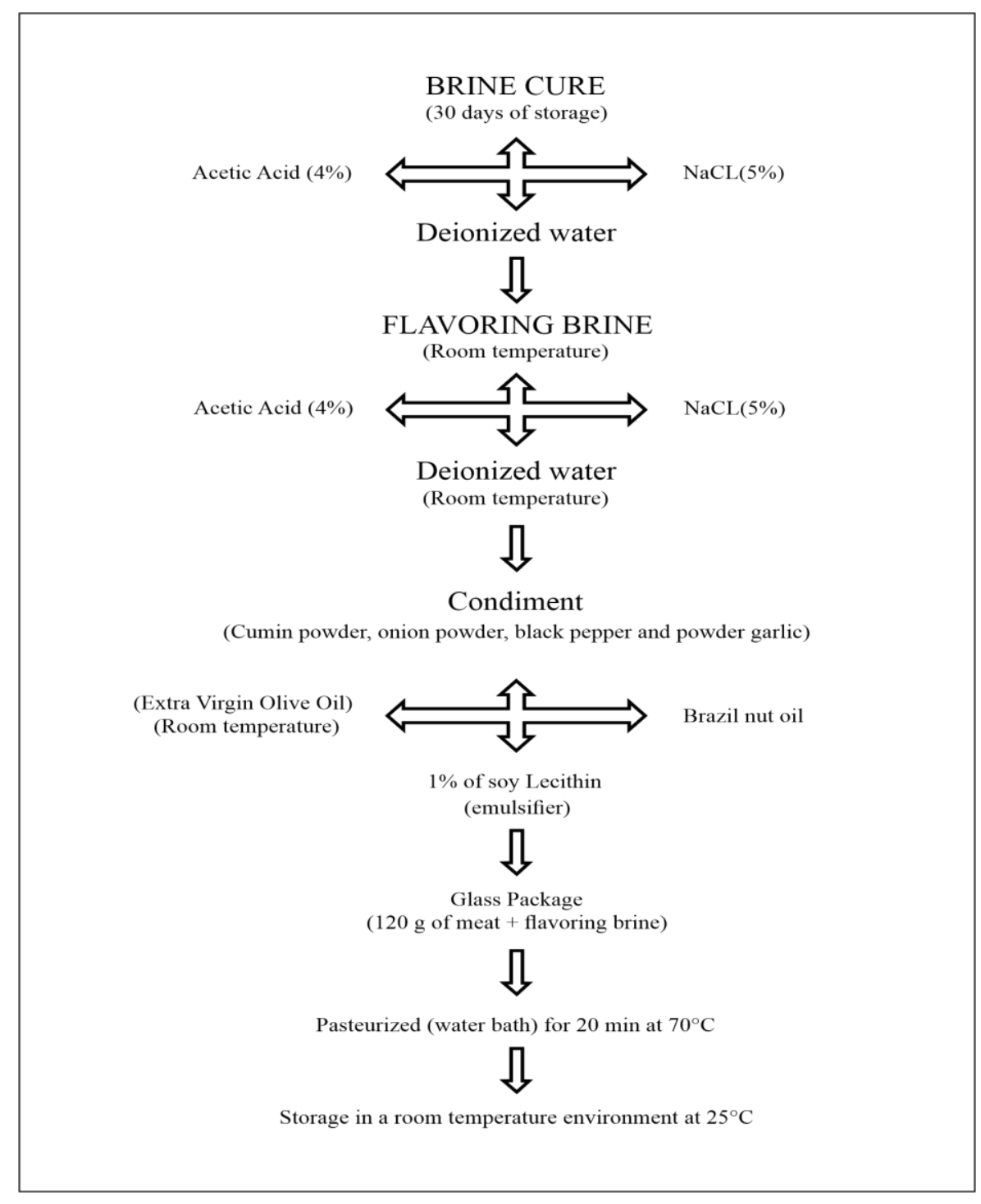

Figure 1. Flowchart of the production of the semi-preserve

\subsection{Assays}

\subsubsection{Proximate Composition}

the products were analyzed according AOAC (2016). Protein analysis was carried out using the Kjeldahl method and crude fat content was determined using the Soxhlet extraction method, Ash determination was done in an oven at $550{ }^{\circ} \mathrm{C}$ and the carbohydrate content was analyzed using the difference method. The moisture content $(m c)$ was determined by means of an electronic balance (SHIMADZU, MOC-120H®, Kyoto, Japan), and adjusted using an infrared dryer by drying about $1 \mathrm{~g}$ of the sample at a temperature of $105^{\circ} \mathrm{C}$, until loss of 


\section{Macrothink}

moisture. All analyses were performed in duplicate and the results were expressed as mean and standard deviation (SD).

\subsubsection{Physical-Chemical Analysis}

(a) $\mathrm{pH}$ was determined by $\mathrm{pH}$ meter readings; (b) titratable acidity was determined using the AOAC method (2016). The products were crushed using mortar and pestle to obtain a slurry, of which about $2.5 \mathrm{~g}$ was weighed out into a $100 \mathrm{ml}$ beaker and $50 \mathrm{ml}$ of distilled water was added. The sample was then titrated with $0.1 \mathrm{~N} \mathrm{NaOH}$ in the presence of a phenolphthalein indicator until the endpoint was reached, which was indicated by a change to the colour pink. The volume $(\mathrm{ml})$ of $\mathrm{NaOH}$ used was recorded and used in determining titratable acidity using the formula:

$\%$ acid $=(\mathrm{ml}$ of $\mathrm{NaOH}$ used $) \times(0.1 \mathrm{~N} \mathrm{NaOH}) \times$ (milliequivalent factor $) \times(100) /$ grams of sample

(c) Total volatile base nitrogen - TVBN as described by Wootlon, \& Chuah (1981) and 10g of sample was homogenized with trichloroacetic acid - TCA $(7.5 \%)$ for extraction. The extract was filtered with $7.5 \%$ TCA using filter paper, completing the volume to $25 \mathrm{ml}$. The filtrate was distilled using an aliquot of $10 \mathrm{ml}$ of sample in $5 \mathrm{ml}$ of saturated boric acid, and then titrated to determine the TVBN content.

\subsubsection{Microbiology}

Salmonella sp., total coliforms and Escherichia coli were analyzed according to APHA (2015).

\subsection{Statistical Analysis}

The data obtained were analyzed using the statistical software SISVAR version 4.0 (Ferreira, 2000), with a significance level of $5 \%$, and when a significant difference was presented, the Tukey test was applied.

\section{Results and Discussion}

\subsection{Proximate Composition}

The results for the proximate composition of BSB, BSO, TMB and TMO (as described in Table 2) showed similar values, which we considered normal since they were prepared with the same proportions of ingredients. 
Table 2. Proximate composition of semi-preserve of Amazonian caiman meat

\begin{tabular}{ccccc}
\hline \multicolumn{5}{c}{ Results $(\mathrm{g} \%)$} \\
Samples $^{1}$ & Protein & Lipids & Ash & Mc \\
BSB & $20.79 \pm 0.1$ & $12.7 \pm 0.1$ & $0.98 \pm 0.1$ & $65.53 \pm 0.2$ \\
BSO & $20.71 \pm 0.2$ & $12.9 \pm 0.1$ & $0.87 \pm 0.1$ & $65.52 \pm 0.2$ \\
TMB & $21.87 \pm 0.1$ & $10.11 \pm 0.1$ & $0.89 \pm 0.2$ & $67.13 \pm 0.2$ \\
TMO & $20.65 \pm 0.1$ & $10.47 \pm 0.1$ & $1.04 \pm 0.2$ & $67.84 \pm 0.1$ \\
\hline
\end{tabular}

${ }^{1}$ TMB (tail meat/Brazil nut); TMO (tail meat/olive oil), BSB (back strap/Brazil nut) and BSO (back strap/olive oil).

The $m c$ of the canned black caiman did not show any variations and the four samples were between 65.53 and $67.84 \%$. This is in accordance with Azevedo et al. (2009), who evaluated samples of different cuts of meat from canned Caiman latirostris and found $m c$ average of $76 \%$, thus demonstrating that there is no significant variation in relation to the specific cuts used in the semi-preserve. However, these authors also cite that the protein and ash contents were $12.4 \%$ and $1.8 \%$, respectively, which is different from those presented in the table above. According to Vicente Neto et al. (2006), the values for proteins and ash can differ according to the species, which is justified by the results presented in our semi-preserve.

Lipids showed no variations between the formulations for BSB, BSO, TMB and TMO. Espírito Santo et al. (2007) using chilled and previously frozen tilapia fillets (Oreochromis niloticus) in the preparation of the semi-preserve, obtained results without great variations in their two formulations, with the mean values of proteins between 12.8-14.2\%; ash 2.9-1.1\%; lipids 1.4-1.0\% and $m c$ 83.6-81.2\%, respectively. According to Espírito Santo et al. (2007), tilapia is considered a fatty fish with $10 \%$ higher lipids; semi-fat fish have a lipid content between $2.5 \%$ and $10 \%$, and lean fish have values below 2.5\%. Azevedo et al. (2009) obtained the highest percentage of lipids in their semi-preserve made with soybean oil, which may be due to the use of oil that is basically composed of lipids and, in the formulation with only the use of seasoning, the lipid content was $1.4 \%$; close to the mean values of $1.4 \%$ found by Espírito Santo et al. (2007). Considering the results of the authors mentioned above, lipid values might be elevated due to the presence of oils in their formulations.

\subsection{Ph And TVBN - Total Volatile Base Nitrogen}

Concerning $\mathrm{pH}$, at the beginning of the tests the level was 6.28 and, during storage, a considerable decrease of this value was observed. According to table 3, the lowest final $\mathrm{pH}$ value (3.33) was in the BSO sample, and all the products therefore attained the desired values as required by current Brazilian legislation, which defines a $\mathrm{pH}$ of <4.6. (Brasil, 2003) for 
commercially sterile low-acidity foods (canned foods). The titratable acidity of the samples suffered practically no alteration during the stabilizing process, thus ensuring microbiological stability. The $\mathrm{pH}$ value can influence amino decarboxylase activity, which is stronger in an acidic environment, with an optimum $\mathrm{pH}$ between 4.0-5.5. Bilgin and Gençcelep, (2015) report that marinated anchovy samples exhibit lower $\mathrm{pH}$ values than other fish product samples because of the use of organic acids.

Table 3. $\mathrm{pH}$ values during 90 days of storage

\begin{tabular}{lcccc}
\hline \multicolumn{1}{c}{ Samples } & \multicolumn{4}{c}{ Cuts $^{1}$} \\
& TMB & TMO & BSO & BSB \\
\hline Meat & $3.57 \pm 0.1^{\mathrm{a} 1}$ & $3.50 \pm 0.1^{\mathrm{a} 1}$ & $3.33 \pm 0.2^{\mathrm{a} 1}$ & $3.45 \pm 0.1^{\mathrm{a} 1}$ \\
Brine & $4.6 \pm 0.2^{\mathrm{a} 2}$ & $4.9 \pm 0.1^{\mathrm{a} 2}$ & $4.61 \pm 0.1^{\mathrm{a} 2}$ & $4.78 \pm 0.1^{\mathrm{a} 2}$ \\
\hline
\end{tabular}

${ }^{1}$ TMB (tail meat/Brazil nut); TMO (tail meat/olive oil), BSB (back strap/Brazil nut) and BSO (back strap/olive oil); Column followed by samme letter do not differ.

At the end of the $90 \mathrm{~d}$. of product evaluation, the TVBN values showed no difference between the two formulations. The values in Table 2 were below the maximum limit of 30.0 mg TVBN/100g, established by Brazilian legislation for fish and derivatives (Brasil, 2001). In our study, the highest mean level was from the TMO sample which presented $15.04 \pm 0.27$ mg TVBN/100 g after 90d. Similarly, Santos et al. (2018) evaluated frozen pirarucu fillets (untreated and without ingredients) and reported a level of $17.55 \pm 0.27 \mathrm{mg}$ TVBN/100 g. Comparing the results with the data from Topuz (2014), the stability of the alligator product was superior to that of the marinated anchovies tested in the aforementioned study. This may have occurred due to the use of pasteurization at $70{ }^{\circ} \mathrm{C} / 20 \mathrm{~min}$. It is also noteworthy that the storage was at room temperature and not at a controlled temperature of $4{ }^{\circ} \mathrm{C}$, as used by Topuz (2014). The authors used two different flavoring solutions in their anchovy semi-preserve: one containing sunflower oil and the other a pomegranate sauce. During the stability evaluation (100 d.), the TVBN values showed great difference between the two formulations in the first stages of storage, with a maximum level of $35 \mathrm{mg}$ TVBN/100g. The use of TVBN as an indicator of alterations in the fish, such as the products of nitrogenous materials, is widely used as a quality index in the evaluation of a variety of products (Zhao et al., 2019). According to Al-Reza et al. (2015) the presence of TVBN in the fish can be explained by two different pathways: (1) As a result of bacterial catalysis through the breakdown of trimethylamine oxide (TMAO) during the storage and (2) from thermal breakdown of proteins, amino acids and other nitrogenous compounds during the heat processing steps. The TVBN content quantifies a wide range of basic volatile compounds, such as NH3, and the results found in our analysis are expressed in Table 4. 
Table 4. TVBN (mg) in semi-preserved black caiman meat analyzed for $90 \mathrm{~d}$

\begin{tabular}{|c|c|c|c|c|c|c|c|}
\hline \multirow{2}{*}{ Meat $^{1}$} & \multicolumn{6}{|c|}{ TVBN $^{2}$ (days) } & \multirow[t]{2}{*}{ Average } \\
\hline & 15 & 30 & 45 & 60 & 75 & 90 & \\
\hline BSO & $7.55 \pm 0.1$ & $\begin{array}{c}12.39 \pm 0 \\
2\end{array}$ & $\begin{array}{c}10.83 \pm \\
0.1\end{array}$ & $\begin{array}{c}17.52 \\
\pm 0.2\end{array}$ & $\begin{array}{c}8.59 \pm \\
0.2\end{array}$ & $18.31 \pm 0.5$ & 11.86 \\
\hline BSB & $\begin{array}{l}11.00 \\
\pm 0.2\end{array}$ & $\begin{array}{c}15.33 \\
\pm 0.2\end{array}$ & $\begin{array}{c}15.00 \pm \\
0.1\end{array}$ & $\begin{array}{c}16.00 \\
\pm 0.5\end{array}$ & $4.0 \pm 0.1$ & $9.33 \pm 0.4$ & 12.52 \\
\hline TMB & $8.59 \pm 0.1$ & $\begin{array}{c}15.32 \pm 0 \\
5\end{array}$ & $\begin{array}{c}19.12 \pm \\
0.5\end{array}$ & $\begin{array}{c}20.35 \pm \\
0.5\end{array}$ & $9.70 \pm 0.5$ & $17.18 \pm 0.5$ & 14.82 \\
\hline TMO & $\begin{array}{c}12.65 \pm \\
0.1\end{array}$ & $\begin{array}{c}12.35 \pm \\
0.2\end{array}$ & $\begin{array}{c}26.35 \pm \\
0.2\end{array}$ & $\begin{array}{c}14.32 \pm \\
0.1\end{array}$ & $\begin{array}{c}12.47 \pm 0 \\
2\end{array}$ & $10.53 \pm 0.2$ & 15.04 \\
\hline
\end{tabular}

${ }^{1}$ TMB (tail meat/Brazil nut); TMO (tail meat/olive oil), BSB (back strap/Brazil nut) and BSO (back strap/olive oil); ${ }^{2}$ Expressed in mg.

\subsection{Microbiological Assays}

As for the microbiological parameters evaluated, all samples met current legislation (Brasil, 2001) for Salmonella sp., total coliforms, and E. coli. The results suggest process efficiency, which resulted in product safety over a period of 90 days when stored at $25^{\circ} \mathrm{C}$. These results are similar to those found by Espírito Santo et al. (2007), who produced semi-preserved tilapia fillets. Edris et al. (2017) evaluated smoked fish (herring and salmon) and semi cooked fish (fish fingers and breaded shrimp), and the no incidence of Salmonella sp., Listeria monocytogenes and Vibrio parahaemolyticus were isolated in the examined samples. Kato et al. (2016) evaluated the binomial time/temperature in tambaqui sous vide. The product was prepared containing soy sauce, water, horseradish and garlic flakes and the values of total coliforms found in the samples analyzed were below the critical level of $10^{2} \mathrm{CFU} / \mathrm{g}$, which is in conformity with Brazilian legislation. Turan et al. (2017) concluded that marination of anchovies with $0.1 \%$ laurel oil can retard lipid oxidation and improve the sensory attributes of the product during refrigerated storage. Oils and extracts can act as antibacterial, antifungal, and promising antioxidant properties, since various chemical components are contained in different parts of the plant from which they are obtained. This therefore plays an important role in maintaining the shelf life of food by preventing its deterioration. During the preparation of the semi-preserve, the percentage of Brazil nut oil and extra virgin olive oil used may have affected the emulsification, thus helping in the microbiological stability. Kocatepe (2019) used four types of essential oils in marinated fish. This was done after the marinating process when the fish fillets were then stored in sunflower oil. The authors concluded that adding different essential oils to cold anchovy marinade prolongs the shelf life. Essential oils are safe for use in marinated anchovies and the product is deemed to be fit for human consumption for a period of 6 months. 


\section{Conclusion}

The production of a semi-preserve using black caiman meat proved to be viable, since it permits better utilization of the meat. In addition, the alligator semi-preserve proved its stability and thus its safety, since the parameters analyzed over $90 \mathrm{~d}$. were in accordance with the safety limits. The Brazil nut oil and olive oil were efficient, and the shelf life of these products was not affected. However, in order to confirm their effectiveness, other analyses should have been carried out, such as those for fungi, and color and biogenic amines.

\section{References}

Al-Reza, S., Karmaker, S., Hasan, M., Roy, S., Hoque, R., \& Rahman, N. (2015). Effect of traditional fish processing methods on the proximate and microbiological characteristics of Laubuka dadiburjori during storage at room temperature. Journal of Fisheries and Aquatic Science, 10(4), 232-243. https://doi.org/10.3923/jfas.2015.232.243

AOAC - Association of Official Analytical Chemists (2016) Official methods of analysis, $20^{\text {th }}$ edition. AOAC International, Gaithersburg, MD, USA.

APHA - American public health association. Compendium of methods for the microbiological examination of foods. (2015). 5 ed. 965 p.

Bilgin, B., \& Gençcelep, H. (2015). Determination of biogenic amines in fish products. Food science and biotechnology, 24(5), 1907-1913. https://doi.org/10.1007/s10068-015-0251-4

Brasil (2001). Resolução RDC no 12 de 02/01/2001. Agência Nacional de Vigilância Sanitária;

Brasil (2005). Resolução RDC n ${ }^{0} 270$, de 22/09/2005. "Regulamento técnico para óleos vegetais, gorduras vegetais e creme vegetal”. Órgão emissor - ANVISA, Agência Nacional de Vigilância Sanitária.

Carpio, K. C. R., Nhavoto, V. M., \& Inhamuns, A. J. (2018). Thermoprocessment of tambaqui fish in tucupi sauce. African Journal of Food Science and Technology, 9(3), 59-64.

Cawthorn, D., \& Hoffmand, L. C. (2016) Controversial cuisine: A global account of the demand, supply, and acceptance of "unconventional" and "exotic" meats. Meat Science 120, 19-36. https://doi.org/10.1016/j.meatsci.2016.04.017

Coutinho, N. M., Canto, A. C. V. C. S., Mársico, E. T., Silva, F. A., Keller, L. A. M., Conte-Junior, C. A., \& Monteiro, M. L. G. (2019). Fatty acid composition and influence of temperature on the lipid stability of Arapaima gigas meat. Brazilian Journal of Food Technology, 22, e2018132. https://doi.org/10.1590/1981-6723.13218

Dantas Filho, J. V., Franck, K. M., Gasparotto, P. H. G., \& Cavali, J. (2020). Development of alligator farms in Brazil. Revista Ciência e Saúde Animal, 2, 32-47.

Dericioglu, B. N., Alak, G., \& Atamanalp, M. (2019). Determining protein denaturation of sardine (Sardina pilchardus) marinates before and after the maturation. Journal of Food Processing and Preservation, 43(9), e14059. https://doi.org/10.1111/jfpp.14059 
Edris, A. A., Fatin, A. H., Fahim, A. E. S., Shaltout, F. A. E., Azza, H. E. \& Nairoz, M. A. (2017). Microbiological Evaluation of Some Heat-Treated Fish Products in Egyptian Markets. EC Nutrition, 12, 124-132.

Espírito Santo, M. L. P., Vivian, V., Mirapalheta, T., Carbonera, N., Coelho, G., \& Damian, C. (2007). Chemical, physical, and microbiological changes in tilapia (Oreochromis niloticus) during marination. Alim. Nutr., 18(1), 1-5.

Ferreira, D. F. (2000). Análises estatísticas por meio do Sisvar para Windows versão 4.0. In: Reunião anual da região brasileira da Sociedade Internacional de Biometria, São Carlos. Anais. São Carlos: UFSCar, 45, 235.

Figueiredo, S. I. S., Araújo, E. G., Araújo, L. B. M., \& Ferraz, R. H. S. (2015). Bone and muscular bases of commercial cuts from the Yacare Caiman (Caiman yacare, Daudin 1802) tail. Arquivo Brasileiro de Medicina Veterinária e Zootecnia, 67(3), 909-917. https://doi.org/10.1590/1678-4162-7787

Isaac, V. J., Almeida, M. C., Giarrizzo, T., Deus, C. P., Vale, R., Klein, G., \& Begossi, A. (2015). Food consumption as an indicator of the conservation of natural resources in riverine communities of the Brazilian Amazon. Anais da Academia Brasileira de Ciências, 87(4), 2229-2242. https://doi.org/10.1590/0001-3765201520140250

Kato, H. C. A., Lourenço, L. F. H., Araújo, E. A. F., Sousa, C. L., Joele, M. R. S., \& Ribeiro, S. C. A. (2016). Change in physical and chemical characteristics related to the binomial time-temperature used in sous pasteurization Tambaqui (Colossoma macropomum). Arquivo Brasileiro de Medicina Veterinária e Zootecnia, 68(1), 224-232. https://doi.org/10.1590/1678-4162-8096

Kluczkovski Júnior, A., Francisco, A., Kluczkovski, A. M., Silveira, R., \& Markendorf, F. (2016). Fatty acid profile of the Amazon caiman protein concentrate. Journal of Food and Nutrition Research, 4, 699-702.

Kocatepe, D., Turan, H., Altan, C. O., Keskin, I., Ceylan, A., Kostekli, B., \& Candan, C. (2019). Influence of different essential oils on marinated anchovy (Engraulis encrasicolus L. 1758) during refrigerated storage. Food Science and Technology, 39, 255-260. https://doi.org/10.1590/fst.01318

Marioni, B., Botero-Arias, R., \& Fonseca-Junior, S.F. (2013). Local community involvement as a basis for sustainable crocodilian management in Protected Areas of Central Amazonia: problem or solution?. Tropical Conservation Science, 6(4), 484-492. https://doi.org/10.1177/194008291300600403

Mesias, M., Holgado, F., Sevenich, R., Briand, J. C., Márquez Ruiz, G., \& Morales, F. J. (2015). Fatty acids profile in canned tuna and sardine after retort sterilization and high-pressure thermal sterilization treatment. Journal of Food and Nutrition Research, 54, 171-178.

Santos, J. S. L., Mársico, E. T., Lemos, M., Cinquini, M. A., Alves da Silva, F., Dutra, Y. 
B., ... Monteiro, M. L. G. (2018). Effect of the UV-C radiation on shelf life of vacuum-packed refrigerated pirarucu (Arapaima gigas) fillets. Journal of aquatic food product technology, 27(1), 48-60. https://doi.org/10.1080/10498850.2017.1402840

Szymczak, M., Felisiak, K., Tokarczyk, G., \& Szymczak, B. (2019). The reuse of brine to enhance the ripening of marine and freshwater fish resistant to marinating. International Journal of Food Science and Technology, 54, 1151-1159. https://doi.org/10.1111/ijfs.14034

Testa, B., Lombardi, S. J., Macciola, E., Succi, M., Tremonte, P., \& Iorizzo, M. (2019). Efficacy of olive leaf extract (Olea europaea) in marinated anchovies (Engraulis encrasicolu) process. Heliyon, 5(5), e01727. https://doi.org/10.1016/j.heliyon.2019.e01727

Topuz, O. K., Yerlikaya, P., Ucak, I., Gumus, B., \& Büyükbenli, H. A. (2014). Effects of olive oil and olive oil-pomegranate juice sauces on chemical, oxidative and sensorial quality of $\begin{array}{lllll}\text { marinated } \quad \text { anchovy. } & \text { Food } & \text { 63-70mistry, }\end{array}$ https://doi.org/10.1016/j.foodchem.2013.12.103

Turan, H., Kocatepe, D., Keskini, I., Altan, C. O., Kostekli, B., Candan, C., \& Ceylan, A (2017). Interaction between rancidity and organoleptic parameters of anchovy marinade (Engraulis encrasicolus L. 1758) include essential oils. J Food Sci Technol, 54(10), 3036-3043. https://doi.org/10.1007/s13197-017-2605-9

Vicente Neto, J., Bressan, M. C., Faria, P. B., Vieira, J. O., Santana, M. T. A., \& Kloster, M. (2006). Composição centesimal e colesterol da carne de jacaré-do-pantanal (Caiman yacare) oriundo de zoocriadouro e habitat natural. Ciência e Agrotecnologia, 30(4), 701-706. https://doi.org/10.1590/S1413-70542006000400016

Wootlon, M., \& Chuah, S. H. (1981). The use of sea mullet (Mugil cephalus) in the production of cold marinades. Food Technology in Australia, 33(8), 392-397.

Zanqui, A. B., da Silva, C. M., Ressutte, J. B., de Morais, D. R., Santos, J. M., Eberlin, M. N., Cardozo-Filho, L., Visentainer, J. V., Gomes, S. T. M., \& Matsushita, M. (2019). Brazil Nut Oil Extraction Using Subcritical n-Propane: Advantages and Chemical Composition. J. Braz. Chem. Soc., 00, 1-10. https://doi.org/10.21577/0103-5053.20190225

Zhao, C. C., Benjakul, S., \& Eun, J. B. (2019). Changes in protein compositions and textural properties of the muscle of skate fermented at $10^{\circ} \mathrm{C}$. International Journal of Food Properties, 22(1), 173-185. https://doi.org/10.1080/10942912.2019.1575396

\section{Copyright Disclaimer}

Copyright for this article is retained by the author(s), with first publication rights granted to the journal.

This is an open-access article distributed under the terms and conditions of the Creative Commons Attribution license (http://creativecommons.org/licenses/by/4.0/). 